\title{
REFERENCES
}

Bell, D. J. (1935). J. chem. Soc. p. 1874.

Campbell, P. N. (1952). Biochem. J. 52, 444.

Cori, C. F., Cori, G. T. \& Green, A. A. (1943). J. biol. Chem. 151, 39.

Cori, G. T. \& Cori, C. F. (1940). J. biol. Chem. 135, 733.

Gill, P. M. \& Lehmann, H. (1939). Biochem. J. 33, 1151.

Gottschalk, A. (1947). Nature, Lond., 160, 113.

Gottschalk, A. (1950). Advanc. Carbohyd. Chem. 5, 49.

Green, A. A. \& Cori, G. T. (1943). J. biol. Chem. 151, 21.

Hagedorn, H. C. \& Jensen, B. N. (1923a). Biochem. Z. 135, 46.

Hagedorn, H. C. \& Jensen, B. N. (1923b). Biochem. Z. 137, 92.

Hanes, C. S. (1939). Proc. roy. Soc. B, 128, 421.

Helferich, B. \& Grünler, S. (1937). J. prakt. Chem. 148, 107.
Helferich, B., Grünler, S. \& Gnüchtel, A. (1937). HoppeSeyl. Z. 248, 85.

Koenigs, W. \& Knorr, E. (1901). Ber. dtsch. chem. Ges. 34, 957.

Lineweaver, H. \& Burk, D. (1934). J. Amer. chem. Soc. 56, 658.

Montgomery, E. M., Richtmyer, N. K. \& Hudson, C. S. (1942). J. Amer. chem. Soc. 64, 690.

Pigman, W. W. \& Goepp, R. M., jun. (1948). Chemistry of Carbohydrates, pp. 67, 98. New York: Academic Press Inc.

Pigman, W. W. \& Richtmyer, N. K. (1942). J. Amer. chem. Soc. 64, 374.

Reithel, F. J. (1945). J. Amer. chem. Soc. 67, 1056.

Zemplén, G. \& Pacsu, E. (1929). Ber. dtsch. chem. Ges. 62, 1613.

\section{Studies on the Biochemistry of Zinc}

\section{FURTHER INVESTIGATIONS ON THE INFLUENCE OF ZINC ON METABOLISM}

\author{
By V. SADASIVAN* \\ Haffkine Institute, Bombay, India
}

(Received 4 May 1951)

Changes in the liver and bones and in the metabolism of nitrogen, phosphorus and sulphur in rats maintained on a stock diet supplemented with zinc have already been reported (Sadasivan, $1951 a, b$ ). It was also observed that on a high-fat, low-protein diet, zinc supplements caused a lowering in fat content of rat livers. In this paper, results are presented of investigations on the metabolism of nitrogen, phosphorus and sulphur and the urinary excretion of uric acid and total creatinine (creatine and creatinine) in rats fed on a high-fat, lowprotein diet supplemented with 0.5 and $1.0 \%$ of zinc oxide. Results of experiments on the influence of the element on the assimilation of fat from the intestines and on the activity of the phosphatases and lipase in the system are also included.

\section{EXPERIMENTAL}

Metabolism experiments. The details of the metabolism experiments have already been described in the previous paper in this series. In the present experiments, the high-fat, low-protein diet described in Part 1 was fed to rats. The daily food intake was recorded and calculated for each 3-day period. The collection of urine, faeces, etc., and their analyses were carried out in the same manner as described in Part 2 (Sadasivan, 1951 b). The first three groups of young rats weighed about $40-50 \mathrm{~g}$. each and were about a month

* Present address: Municipal Laboratory, Municipal Buildings, Fort Bombay, 1. old, while groups 4 and 5 were older ones weighing between 90 and $100 \mathrm{~g}$. and 2-2.5 months old. Younger and older rats were compared because preliminary observations suggested that younger rats are probably more susceptible to the effects of zinc than older ones.

For the experiment on fat metabolism, each group consisted of six rats equally distributed between the sexes and litters. Both the groups were fed the high-fat diet, the second group receiving, in addition, $\mathrm{ZnO}$ at $0.5 \%$ level. The faeces were collected for each 3-day period over the experimental period of 15 days and the fat content of the dried faeces was determined by extraction with ether in a Soxhlet extractor. For the determination of fat in the liver, the animals were killed at the end of the experiment. The liver was removed, freed of blood by pressing lightly against blotting paper and ground with a small amount of acetone in a mortar. Fat was then extracted in a Soxhlet extractor with acetone.

Determination of phosphatase activity. Two groups of six rats, each weighing between 60 and 80 g., were fed the stock diet described in Part 1. The second group received, in addition, $\mathrm{ZnO}$ at $1.0 \%$ level of diet. At the end of 15 days, the animals were killed and liver, small intestines, kidneys and femurs were removed for the determination of phosphatase activity. The tissues were freed of blood by washing once with distilled water and femurs cleaned of adhering flesh. Portions of the tissues and the whole of the femurs were prepared for determination of activity according to the method of Bodansky (1937) and of Martland \& Robison (1929). Activity was measured in sample portions of the material suspended in $0.033 \mathrm{M}$-veronal-acetate buffer adjusted to a $\mathrm{pH}$ of 9.1. Sodium $\beta$-glycerophosphate at concentrations of $1.0 \%$ served as substrate and the mixture 
was incubated at $37^{\circ}$ for $1 \mathrm{hr}$. at the end of which inorganic $\mathbf{P}$ was determined by the method of Fiske \& Subbarow (1925) with due correction for the presence of phosphate in the crude enzyme preparations by running parallel controls in all cases.

Determination of lipase activity. An active preparation of pancreatic lipase of rats was prepared by treating fresh, minced pancreas from healthy rats with an excess of pure acetone, grinding in a mortar and filtering after contact with acetone for about half an hour. The process was repeated twice and the residue dried in vacuo. This powder was extracted with glycerol for $24 \mathrm{hr}$., filtered through muslin and the extract used as the source of the enzyme. To test the activity, $2 \mathrm{ml}$. portions of a $5 \%$ extract were added to $5 \mathrm{ml}$. $0.033 \mathrm{M}$-veronal-acetate buffer adjusted to the $\mathrm{pH}$ required and $4 \mathrm{ml}$. of pure olive oil added as substrate. After the additions had been made, the final volume was made to $15 \mathrm{ml}$. with water and the mixture incubated at $37^{\circ}$ for $3 \mathrm{hr}$. after which $25 \mathrm{ml}$. of neutralized ethanol were added and the acid liberated by the enzyme determined by titration against $0.1 \mathrm{~N}-\mathrm{NaOH}$ using phenolphthalein as the indicator. $\mathrm{ZnSO}_{4}, \mathrm{NaCN}, \mathrm{CaCl}_{2}$ etc., used in the experiments, were of Merck's purest grade.

\section{RESULTS AND DISCUSSION}

Metabolism on a high-fat diet. Table 1 summarizes the results of metabolism of nitrogen, phosphorus, etc., obtained for the duration of the experiment when the animals were fed a high-fat, low-protein diet supplemented with zinc. It may be concluded from these results that on a high-fat, low-protein diet, the changes in metabolism of the various constituents studied are similar to those on a stock diet reported in the previous paper. The adverse effect of zinc supplements on the assimilation of phosphate from the intestines does not appear to be due to the precipitation of phosphate in the insoluble form as in beryllium rickets (Kay \& Skill, 1934). The figures in Table 2 show that the quantities of zinc ingested in the animals in the different groups were much less than required to precipitate the phosphate completely. Thus, though a fairly good proportion of the phosphates in the synthetic diet

Table 1. Influence of dietary zinc on the excretion and retention of $\mathrm{N}, \mathrm{P}$ and $\mathrm{S}$ and on the excretion of uric acid and total creatinine by rats fed on a high-fat, low-protein diet

(Summary of results for the whole period of experiment. All values expressed as mean \pm s.E.)

\begin{tabular}{|c|c|c|c|c|c|}
\hline & \multicolumn{3}{|c|}{ Young rats } & \multicolumn{2}{|c|}{ Older rats } \\
\hline & Control & $\begin{array}{c}\text { Zinc fed at } \\
0.5 \% \text { level } \\
\text { as } \mathrm{ZnO}\end{array}$ & $\begin{array}{c}\text { Zinc fed at } \\
1.0 \% \text { level } \\
\text { as } \mathrm{ZnO}\end{array}$ & Control & $\begin{array}{c}\text { Zinc fed at } \\
0.5 \% \text { level } \\
\text { as } \mathrm{ZnO}\end{array}$ \\
\hline Food intake (g.) & $57 \pm 8 \cdot 3$ & $37 \pm 2 \cdot 0$ & $30 \pm 1 \cdot 7$ & $69 \pm 0 \cdot 7$ & $67 \pm 1 \cdot 1$ \\
\hline Change in body weight (g.) & $+5 \pm 4 \cdot 4$ & $-5 \pm 4 \cdot 7$ & $-11 \pm 1 \cdot 3$ & $+0 \cdot 5 \pm 2 \cdot 1$ & $+0.5 \pm 1.9$ \\
\hline $\begin{array}{l}\text { Metabolism of nitrogen (mg.): } \\
\text { Urinary excretion } \\
\text { Faecal excretion } \\
\text { Retention }\end{array}$ & $\begin{array}{r}62 \pm 4 \cdot 5 \\
65 \pm 8 \cdot 4 \\
578 \pm 91\end{array}$ & $\begin{array}{c}71 \pm 14 \cdot 1 \\
93 \pm 4 \cdot 3 \\
311 \pm 34\end{array}$ & $\begin{array}{c}78 \pm 11 \\
97 \pm 6 \\
195 \pm 18\end{array}$ & $\begin{array}{l}142 \pm 31 \\
103 \pm 8 \\
600 \pm 64 \cdot 5\end{array}$ & $\begin{array}{l}100 \pm 11 \\
151 \pm 5 \\
584 \pm 58\end{array}$ \\
\hline $\begin{array}{l}\text { Metabolism of phosphorus (mg.) } \\
\text { Urinary excretion } \\
\text { Faecal excretion } \\
\text { Retention }\end{array}$ & $\begin{array}{c}30 \pm 3 \cdot 6 \\
21 \pm 1 \cdot 5 \\
232 \pm 37 \cdot 9\end{array}$ & $\begin{array}{r}20 \pm 3 \cdot 9 \\
49 \pm 7 \cdot 8 \\
114 \pm 7 \cdot 1\end{array}$ & $\begin{array}{l}16 \pm 3 \cdot 7 \\
71 \pm 9 \cdot 4 \\
61 \pm 6 \cdot 2\end{array}$ & $\begin{array}{c}70 \pm 12 \cdot 2 \\
32 \pm 3 \cdot 0 \\
241 \pm 28\end{array}$ & $\begin{array}{c}36 \pm 3 \cdot 5 \\
125 \pm 11 \\
155 \pm 16 \cdot 1\end{array}$ \\
\hline $\begin{array}{l}\text { Metabolism of sulphur (mg.): } \\
\text { Urinary excretion } \\
\text { Faecal excretion } \\
\text { Retention }\end{array}$ & $\begin{array}{l}10 \cdot 2 \pm 0 \cdot 17 \\
15 \cdot 4 \pm 0 \cdot 55 \\
-1 \cdot 3 \pm 3 \cdot 1\end{array}$ & $\begin{aligned} 9 \cdot 6 & \pm 0 \cdot 2 \\
18 \cdot 2 & \pm 0 \cdot 55 \\
-12 \cdot 0 & \pm 0 \cdot 8\end{aligned}$ & $\begin{array}{r}8 \cdot 8 \pm 0 \cdot 14 \\
19 \cdot 4 \pm 0 \cdot 65 \\
-15 \cdot 9 \pm 1 \cdot 0\end{array}$ & $\begin{array}{c}8 \cdot 8 \pm 1 \cdot 43 \\
18 \cdot 5 \pm 0 \cdot 6 \\
2 \cdot 8 \pm 2 \cdot 6\end{array}$ & $\begin{array}{c}8 \cdot 12 \pm 1 \cdot 1 \\
26 \cdot 3 \pm 1 \cdot 8 \\
-4 \cdot 9 \pm 0 \cdot 6\end{array}$ \\
\hline Uric acid in urine (mg.) & $1 \cdot 61 \pm 0 \cdot 23$ & $1.57 \pm 0.54$ & $1 \cdot 0 \pm 0 \cdot 79$ & $4 \cdot 58 \pm 1 \cdot 7$ & $-4 \cdot 9 \pm 0 \cdot 6$ \\
\hline Total creatinine in urine (mg.) & $11 \cdot 85 \pm 7 \cdot 1$ & $8 \cdot 73 \pm 3 \cdot 8$ & $6 \cdot 87 \pm 0 \cdot 9$ & $12 \cdot 6 \pm 2 \cdot 9$ & $10 \cdot 83 \pm 0.9$ \\
\hline
\end{tabular}

Table 2. Quantities of zinc and phosphorus in the diet of rats supplemented with zinc

(High-fat, low-protein diet in all groups.)

\begin{tabular}{|c|c|c|c|c|c|}
\hline $\begin{array}{c}\text { Group } \\
\text { no. }\end{array}$ & Supplement to diet & $\begin{array}{l}\text { Intake of } \\
\text { food during } \\
15 \text { days } \\
\text { (g.) }\end{array}$ & $\begin{array}{l}\text { Intake of } \\
\mathrm{ZnO} \text { in diet } \\
\quad \text { (mg.) }\end{array}$ & $\begin{array}{l}\text { Phosphorus } \\
\text { in diet } \\
\text { (mg.) }\end{array}$ & $\begin{array}{l}\text { Amount of } P \\
\text { precipitable by } \\
\mathrm{Zn} \text { in diet } \\
\text { (mg.) }\end{array}$ \\
\hline $\begin{array}{l}2 \\
3 \\
5\end{array}$ & $\begin{array}{l}0.5 \% \mathrm{ZnO} \\
1.0 \% \mathrm{ZnO} \\
0.5 \% \mathrm{ZnO} \text { (older rats) }\end{array}$ & $\begin{array}{l}36 \cdot 65 \\
29 \cdot 70 \\
67 \cdot 00\end{array}$ & $\begin{array}{l}190 \cdot 6 \\
305 \cdot 9 \\
348 \cdot 4\end{array}$ & $\begin{array}{l}183 \cdot 25 \\
148 \cdot 50 \\
335 \cdot 00\end{array}$ & $\begin{array}{l}\mathbf{4 7 \cdot 6 5} \\
76 \cdot 48 \\
87 \cdot 10\end{array}$ \\
\hline
\end{tabular}


remained in an assimilable form, the quantity actually assimilated appeared small.

Zinc and phosphatase activity. The decrease in the assimilation of phosphorus from the intestines and the poor development of the bones consequent on the intake of zinc in the concentrations studied suggest that zinc affects adversely some process of phosphorus metabolism. To check this point, the phosphatase activity of the tissues of zinc-fed

Table 3. Phosphatase activity of tissues of rats fed on a stock diet supplemented with zinc

(For method see text. Results as mean \pm S.F.)

\begin{tabular}{lll} 
& \multicolumn{2}{c}{ P liberated (mg.) } \\
\cline { 2 - 3 } Control & \multicolumn{1}{c}{ Zinc-fed } \\
Intestines & $0.615 \pm 0.04$ & $0.499 \pm 0.01$ \\
Liver & $0.069 \pm 0.005$ & $0.116 \pm 0.005$ \\
Bones (femur) & $0.103 \pm 0.007$ & $0.133 \pm 0.019$ \\
Kidneys & $0.253 \pm 0.01$ & $0.477 \pm 0.02$
\end{tabular}

animals was compared with that of normal ones. The results (Table 3) show that the intake of zinc at the level investigated brings about a significant decrease in phosphatase activity of the intestine while increasing it in the liver and kidneys. The difference in the activity of the bones does not appear to be significant (cf. Hove, Elvehjem \& Hart, 1940).

Zinc and fat metabolism. The importance of phosphorylation in the absorption of triglyceride fat from the intestines has been investigated by several workers, and the literature on the subject has been reviewed by Frazer (1946). If assimilation of fat is closely related to and dependent on its phosphorylation in the intestines, the impairment of phosphate assimilation from the organ should result in an increase in the faecal fat with or without a simultaneous decrease in the fat intake. In our experiments no appreciable difference in the faecal excretion of fat could be observed, it being $0.84 \mathrm{~g}$. \pm 0.05 and $0.71 \mathrm{~g} . \pm 0.05$ per rat in the control and zinc-fed groups respectively for the experimental period of 15 days. The corresponding figures for fat intake during the period were $29 \cdot 3 \mathrm{~g} \cdot \pm 1 \cdot 08$ and $21.3 \mathrm{~g} . \pm 1.36$ and for fat content of liver, $1.69 \mathrm{~g}$. \pm 0.1 and $0.68 \mathrm{~g} . \pm 0.09$.

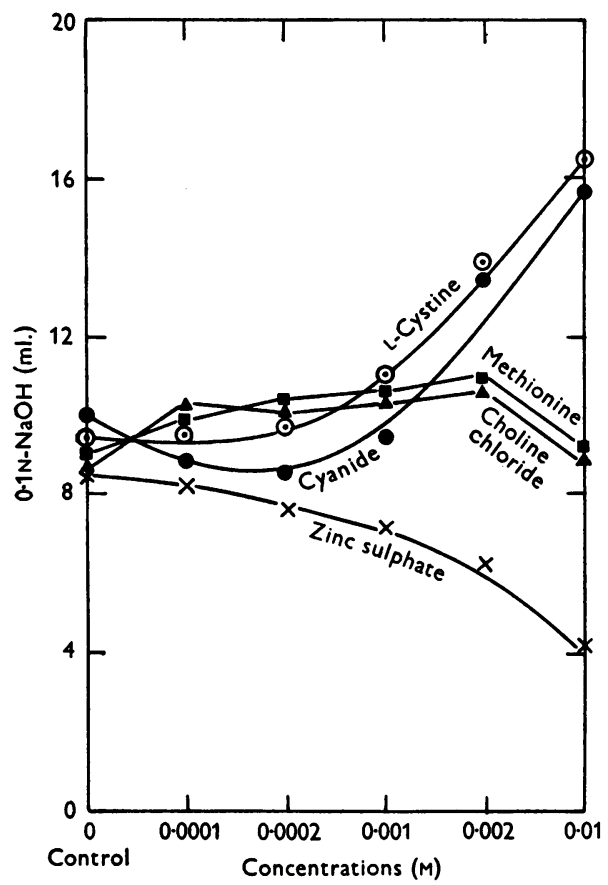

Fig. 1. Influence of zinc, cystine, $\mathrm{NaCN}$, etc., on the lipolytic activity of pancreatic lipase of rats at $\mathrm{pH} 8.2$ and in the presence of $\mathrm{Ca}^{++}$ions.

Zinc and lipolytic activity of pancreatic lipase. The influence of zinc on the fat content of liver was further investigated by testing its effect on the lipolytic activity of pancreatic lipase, and the results of experiments in which zinc sulphate, sodium cyanide and L-cystine were added at a concentration of $0.01 \mathrm{~m}$ to pancreatic lipase with and without prior addition of calcium chloride and at two different $\mathrm{pH}$ values $(6.8$ and $8 \cdot 2)$ are presented in Table 4. In another experiment, the effect of different concentrations of these substances and

Table 4. Influence of zinc and cystine on the lipolytic activity of pancreatic lipase of rats

(For method see text.)

Control

Control $+0.01 \mathrm{~m}-\mathrm{NaCN}$

Control $+0.01 \mathrm{M}-\mathrm{ZnSO}_{4}$

Control + 0.01 M-L-cystine

Control + $20 \mathrm{mg}$. $\mathrm{CaCl}_{2}$

Control $+20 \mathrm{mg}$. $\mathrm{CaCl}_{2}+0.01 \mathrm{M}-\mathrm{NaCN}$

Control $+20 \mathrm{mg}$. $\mathrm{CaCl}_{2}+0 \cdot 01 \mathrm{~m}-\mathrm{ZnSO}_{4}$

Control $+20 \mathrm{mg}$. $\mathrm{CaCl}_{2}+0.01$ M-L-cystine

\begin{tabular}{|c|c|}
\hline \multicolumn{2}{|c|}{$(\mathrm{ml} .0 \cdot 1 \mathrm{~N}-\mathrm{NaOH})$} \\
\hline pH 8.2 & $\mathrm{pH} 6.8$ \\
\hline $11 \cdot 4$ & $7 \cdot 8$ \\
\hline $15 \cdot 0$ & $14 \cdot 4$ \\
\hline $12 \cdot 6$ & $4 \cdot 8$ \\
\hline $15 \cdot 9$ & $7 \cdot 5$ \\
\hline $20 \cdot 7$ & $5 \cdot 4$ \\
\hline 30.9 & $14 \cdot 1$ \\
\hline $13 \cdot 2$ & $8 \cdot 4$ \\
\hline $29 \cdot 4$ & $6 \cdot 0$ \\
\hline
\end{tabular}


also of the two well known lipotropic factors, choline and methionine, on the activity of the enzyme at a $\mathrm{pH}$ of 8.2 in the presence of $\mathrm{Ca}^{++}$ions was tested. The results, presented in Fig. 1, show clearly that both cystine and cyanide increase the lipolytic activity of the enzyme under the conditions specified. This effect of cystine may be related to its known influence on the accumulation of fat in the liver of rats fed on a diet low in lipotropic factors (Beeston \& Channon, 1936; Tucker \& Eckstein, 1937; Mulford \& Griffith, 1942). The significance of results obtained when zinc and cyanide were added is not at present clear and merits further investigation.

\section{SUMMARY}

1. The changes in the metabolism of nitrogen, phosphorus and sulphur and in urinary excretion of uric acid and total creatinine (creatine and creati- nine) in rats fed on a high-fat diet supplemented with zinc have been shown to be similar to those observed for a stock diet. It has also been shown that the decreased assimilation of phosphate from the intestines is not due to its being precipitated as insoluble zine phosphate.

2. Zinc supplements at the levels investigated affected phosphatase activity of the tissues. While the activity of intestinal alkaline phosphatase was lowered, there was an increase in activity in the liver and kidneys in the supplemented groups.

3. Though zinc supplements lowered the fat content of the liver and the assimilation of phosphate from the intestines, there appeared to be no change in the excretion of fat in the faeces.

4. The influence of zinc and other substances such as choline, methionine, L-cystine and cyanide on the lipolytic activity of pancreatic lipase of the rat was also investigated.

\title{
REFERENCES
}

Beeston, A. W. \& Channon, H. J. (1936). Biochem. J. 30, 180.

Bodansky, O. (1937). J. biol. Chem. 118, 341.

Fiske, C. H. \& Subbarow, Y. (1925). J. biol. Chem. 66, 375.

Frazer, A. C. (1946). Physiol. Rev. 26, 103.

Hove, E., Elvehjem, C. A. \& Hart, E. B. (1940). J. biol. Chem. 134, 425.
Kay, H. D. \& Skill, D. I. (1934). Biochem. J. 28, 1222.

Martland, M. \& Robison, R. (1929). Biochem. J. 23, 237.

Mulford, D. J. \& Griffith, W. G. (1942). J. Nutrit. 23, 91.

Sadasivan, V. (1951 a). Biochem. J. 48, 527.

Sadasivan, V. (195ib). Biochem. J. 49, 186.

Tucker, H. F. \& Eckstein, H.'C. (1937). J. biol. Chem. 121 479.

\section{Some Biochemically Relevant Properties of $\boldsymbol{N}$-Substituted Fructosamines Derived from Amino-Acids and $N$-Arylglucosylamines}

\author{
By A. GOTTSCHALK \\ The Walter and Eliza Hall Institute of Medical Research, Melbourne, Australia
}

(Received 15 January 1952)

$N$-Substituted glucosamines ( $N$-acetyl-D-glucosamine, $N$-formyl-D-glucosamine, $N$-methyl-L-glucosamine), derived from 2-amino-2-deoxyglucose, are well known as components of polysaccharides and mucoproteins produced by animal cells, fungi and bacteria. Fructosamine (1-amino-1-deoxyfructose) (also called isoglucosamine) and $N$-substituted fructosamines have not been found among the hydrolytic products of polysaccharides and mucoproteins. It was, however, recently shown (Gottschalk, 1951) that an enzyme present at the surface of the influenza virus splits off from a homogeneous mucoprotein, isolated from human urine (Pye, to be published), an $N$-substituted fructosamine characterized as a condensation product of a ketose and an amino-acid.
$N$-Substituted fructosamines (III, p. 459) are prepared chemically from the so-called $N$-glucosides of primary aromatic amines ( $N$-arylglucosylamines, $\mathrm{I}$, p. 459) through the Amadori rearrangement. Thus $N$-arylglucosylamines from $p$-toluidine, $p$-phenetidine and 3:4-dimethylaniline are transformed to the corresponding fructosamines when heated for a few hours in ethanolic solution with a weak acid as catalyst (Kuhn \& Weygand, 1937; Weygand, 1939, 1940). The isomerization of glucosylamines to fructosamines, i.e. the rearrangement of a $D$ glucose to a $D$-fructose derivative, has been observed with $N$-arylglucosylamines only. So far attempts to induce the Amadori rearrangement in $N$-alkylglucosylamines have failed (Mitts \& Hixon, 1944). While continuing our investigations into the inter- 